\title{
Molecular analysis for sex determination in forensic dentistry: a systematic review
}

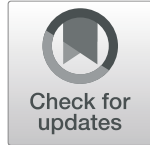

Chaerita Maulani ${ }^{1}$ and Elza Ibrahim Auerkari ${ }^{2 *}$ (D)

\begin{abstract}
Background: Sex determination can be useful in forensic casework, such as in mass disasters, transportation accidents, and cases of a missing person or sexual assault. The remnants of the body can be traced by DNA of the victim, using samples from various sources such as teeth, oral epithelial tissue, and saliva.

Main body: The review aimed to describe research in forensic dentistry with DNA source from the oral region and methods of the applied DNA analysis. A search in PubMed, Google Scholar, and Scopus electronic databases from 2009 to 2019 was conducted to include studies according to PRISMA guidelines. Ten studies were eligible for the review. Genetic markers originated from dentin, dental pulp, saliva, or epithelial cells from buccal tissue and prosthesis. The applied DNA analysis methods were PCR, real-time PCR, and nested PCR.

Conclusions: The published articles mostly showed successful DNA extraction and sex determination, but the rate of success declined as the sample source underwent manipulation to mimic the forensic conditions. Amelogenin, SRY, and DYS14 were reliable indicators for sex determination. Molecular analysis has proved to be efficient and accurate, but the daily forensic practice must select the most appropriate method according to the available body remnants.
\end{abstract}

Keywords: Sex determination, Forensic odontology, Amelogenin, SRY, DYS14

\section{Background}

In identifying human remains, the sex determination is an essential part besides assessing age and ethnic origin. Sex determination is needed for estimating age and stature and can cut the number of possible matches in half (Macaluso 2010). Identification of the victim's body corpse in forensic can be performed using varying methods, such as using stages of third molar development (Luthfi et al. 2017), using palatal rugae for edentulous corpse (Basman et al. 2018; Suhartono et al. 2016), using teeth measurement (Silva et al. 2016), or using DNA source (Roewer 2019).

In the forensic cases, the remains of the deceased may have suffered, e.g., incineration, trauma, decomposition, or immersion in the sea. Teeth are the hardest tissue in

\footnotetext{
* Correspondence: eauerkari@yahoo.com

${ }^{2}$ Department of Oral Biology, Faculty of Dentistry, Universitas Indonesia, Jakarta, Indonesia

Full list of author information is available at the end of the article
}

the body and often remain intact after death, which makes them useful for forensic identification (da Silva et al. 2007). DNA is the most reliable source with high accuracy in sex determination when compared to other non-metric and metric measurements (Capitaneanu et al. 2017a). The molecular indicators for forensic sex determination, based on PCR analysis, included amelogenin, SRY, DXYS156, and TSPY (Butler and Li 2014; Mukerjee et al. 2013).

Amelogenin is widely used as a marker for sex typing. Amelogenin is a protein of epithelial origin, with the gene related to both $\mathrm{X}$ and $\mathrm{Y}$ chromosomes (Nakahori et al. 1991). One associated location is in the distal short arm of the $\mathrm{X}$ chromosome in the p.22.1-p.22.3 region, and the other one is located near the centromere of the Y chromosome (Sasaki and Shimokawa 1995). Amelogenin is involved in dental development early in life. Previously only known from enamel, amelogenin has also been discovered in long bone cells (Bansal et al. 2012). Although widely 
used as a marker, in some cases, deletion in the amelogenin $Y$ region or lack of Y-DNA has been found although the $\mathrm{Y}$ chromosome was present. Thus, this method in some cases misidentified males as females, leading to the wrong conclusions (Chen et al. 2014; Ou et al. 2011).

Subsequent research has found other methods that are more reliable in sex-typing. The sex-determining region $\mathrm{Y}$ (SRY) is a sex-typing based on the Y chromosome (Sinclair et al. 1990). The product of the SRY gene is an HMG box protein whose DNA-binding activity is vital for testis formation (Harley and Goodfellow 1994). The presence of the amplified product from the SRY gene may indicate a male (but not female) genotype (Morikawa et al. 2011). The SRY gene is located on the short arm of the Y chromosome at p11-31 (US National Library of Medicine 2019). SRY is a powerful marker for forensic sex-typing because the gene product of SRY has a direct link with male development. This makes SRY a reliable biological predictor of male sex (Chen et al. 1994).

Chen et al. first described DXYS156 as a pentanucleotide microsatellite that maps both sex chromosomes to the pseudoautosomal region and helps in determining sex. DXYS156 is multi-allelic with demographically restricted alleles to indicate the probable geographic or ethnic origin of the individual. The Y-specific alleles can be also distinguished from their chromosomal $\mathrm{X}$ counterpart due to the insertion of adenine into the repeat units of (TAAAA) (Chen et al. 1994).

TPSY, or "Y-encoded testis-specific protein," is the product of a human proximal Yp tandem gene cluster. TPSY is located on the proximal part of human Yp11.2 and it is Y-specific (Jacot et al. 2013). The Y chromosome-specific DNA can be detected by TPSY because it is sensitive in detecting the $Y$ chromosome. This is useful in cases of sexual assault, with a mixture of male and female DNA (Kamodyova et al. 2013). Originally, TPSY was defined by the DYS14 genomic probe, which is located in intron 1 of TPSY (Campos et al. 2014).

The problem of samples containing only degraded DNA in practical forensic cases can hinder the analysis or reduce the resolution. In such cases, degraded DNA may offer limited or no chance for analysis or definite conclusion (Rubio et al. 2009). In these cases, some studies have treated the DNA sources for mimicking the degradation of actual forensic samples.

\section{Methods}

\section{Study protocol}

The present study was done according to the guidelines of Preferred Reporting Items for Systematic Reviews and Meta-Analyses (PRISMA) which were used in this context (Moher et al. 2009).

\section{Search strategy}

A systematic search was performed in PubMed/MEDLINE, Scopus, and Google Scholar databases for the period 2009-2019. The main keywords for the search were sex determination OR sex estimation OR sex identification OR gender determination OR gender estimation OR gender identification OR sexual dimorphism AND forensic dentistry OR forensic odontology AND molecular analysis OR biochemical analysis.

\section{Eligibility criteria}

Articles were screened by title and abstract, and then possible inclusion of full article was selected. The fulltext articles corresponding to all inclusion and exclusion criteria were eligible for final inclusion. The inclusion and exclusion criteria were defined by the authors. The inclusion criteria were studies describing sex estimation in forensic dentistry; samples obtained from the oral region; molecular analyses by polymerase chain reaction (PCR) technique, real-time polymerase chain reaction (RT-PCR), or nested polymerase chain reaction (nested PCR); no restriction for sample size; age if any; studies in English language; and articles in the past 10 years (2009-2019). The exclusion criteria were anthropological sex estimation, studies without abstract, abstract without full paper, non-metric and metric teeth analysis for sex estimation, and histological analysis.

\section{Data collection}

The articles were first screened in accordance with the abovementioned keywords in their title and abstract. The second screening was performed based on the inclusion and exclusion criteria to find relevant full-text articles and the eligible articles were selected. The fulltext articles were read and assessed by individual reviewers independently to regain relevant data for review.

\section{Results}

\section{Literature search and screening}

The selection process of the study screening protocol is shown in Fig. 1. The total number of initially retrieved published articles from 2009 to 2019 was 1375. Removal of duplicates left 1360 articles for screening. Of these, 1187 articles were excluded by titles and abstracts, leaving 173. After the further full-text screening, ten articles were found as eligible studies. The procedure of the selection process is presented in Fig. 1.

\section{Data extraction}

The data of each article, including the name of the first author, year of publication, sample source, age (years old), DNA concentration, treatment, DNA extraction, analysis method, technique, result, and conclusion, were extracted and listed in Table 1. 


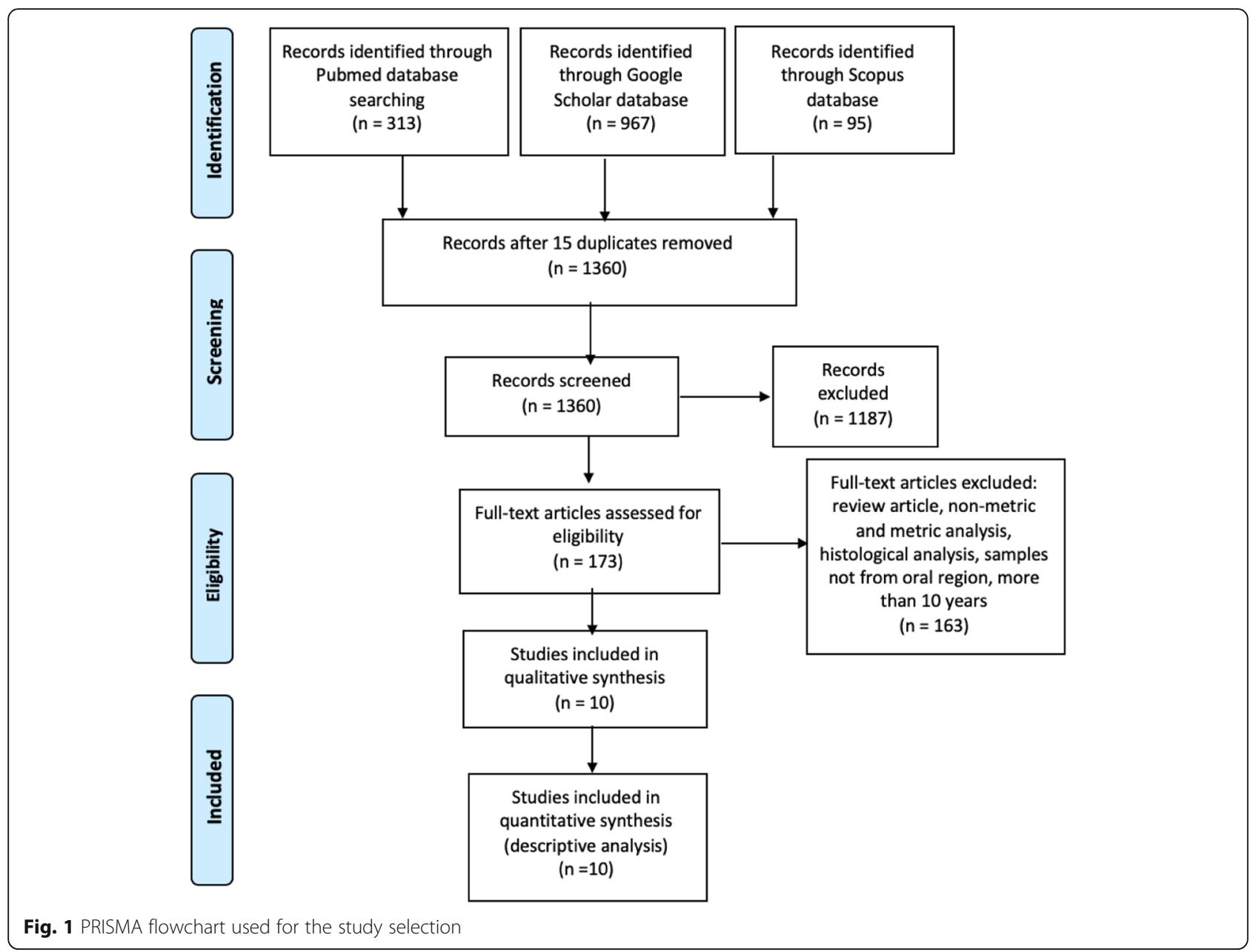

\section{Molecular analysis for sex determination in forensic dentistry findings}

These ten studies included 335 samples, and three studies mention samples originating from male and female subjects (Nakanishi et al. 2015; Kholief et al. 2017; Bharath et al. 2019). Samples were acquired from different parts of the oral region, including from whole teeth (Srivastava et al. 2017; Lim et al. 2019), dentin or dental pulp (Zapico and Ubelaker 2013; Kholief et al. 2017; Dutta et al. 2017; Chowdhury et al. 2018), epithelial cells from toothbrush, intraoral, dental prosthesis (Reddy et al. 2011; Nakanishi et al. 2015; Bharath et al. 2019), and saliva from dental prosthesis (Chauhan et al. 2016). Three studies mention the age of sampled subjects who were 19-81 years old (Zapico and Ubelaker 2013; Kholief et al. 2017; Bharath et al. 2019). The other studies do not mention the subject's age (Reddy et al. 2011; Nakanishi et al. 2015; Chauhan et al. 2016; Srivastava et al. 2017; Dutta et al. 2017; Chowdhury et al. 2018; Lim et al. 2019).

Three studies used DNA without any treatment for the samples, while others were grouping the sample into categories of forensic insult. Degraded DNA was achieved by storage for certain time span (Reddy et al. 2011), incineration (Dutta et al. 2017; Chowdhury et al. 2018; Lim et al. 2019), immersion in saltwater (Dutta et al. 2017; Chowdhury et al. 2018), desiccation at room temperature (Reddy et al. 2011; Dutta et al. 2017; Chowdhury et al. 2018), burial in soil (Chowdhury et al. 2018), and/or illumination by ultra-violet radiation (Nakanishi et al. 2015).

DNA extraction was performed by Chelex-100 (Reddy et al. 2011; Bharath et al. 2019), silica-based (Zapico and Ubelaker 2013; Chauhan et al. 2016; Kholief et al. 2017), silica-coated magnetic particle (Nakanishi et al. 2015), or phenol-chloroform method (Srivastava et al. 2017; Dutta et al. 2017; Chowdhury et al. 2018; Lim et al. 2019). The methods of analysis in the studies included the amelogenin method (Srivastava et al. 2017; Dutta et al. 2017; Chowdhury et al. 2018; Lim et al. 2019), amelogenin with $\beta$-actin (Zapico and Ubelaker 2013), amelogenin without copy number variation (CNV) region (Nakanishi et al. 2015), amelogenin and 15 CODIS loci (Chauhan et al. 2016), SRY (Reddy et al. 2011; Bharath et al. 2019), and combined DYS14 along with SRY (Kholief et al. 2017). DNA amplification was conducted using PCR 


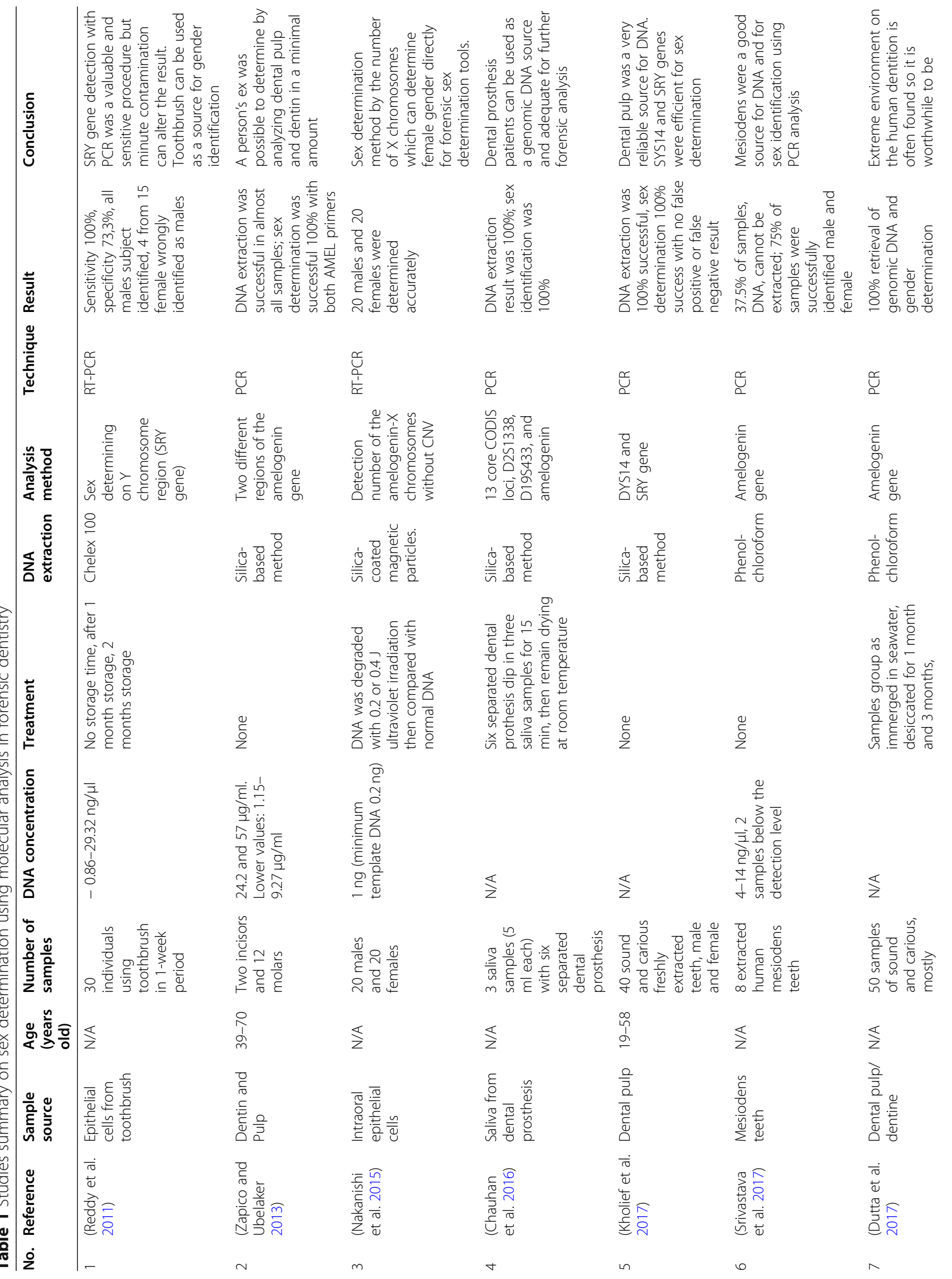




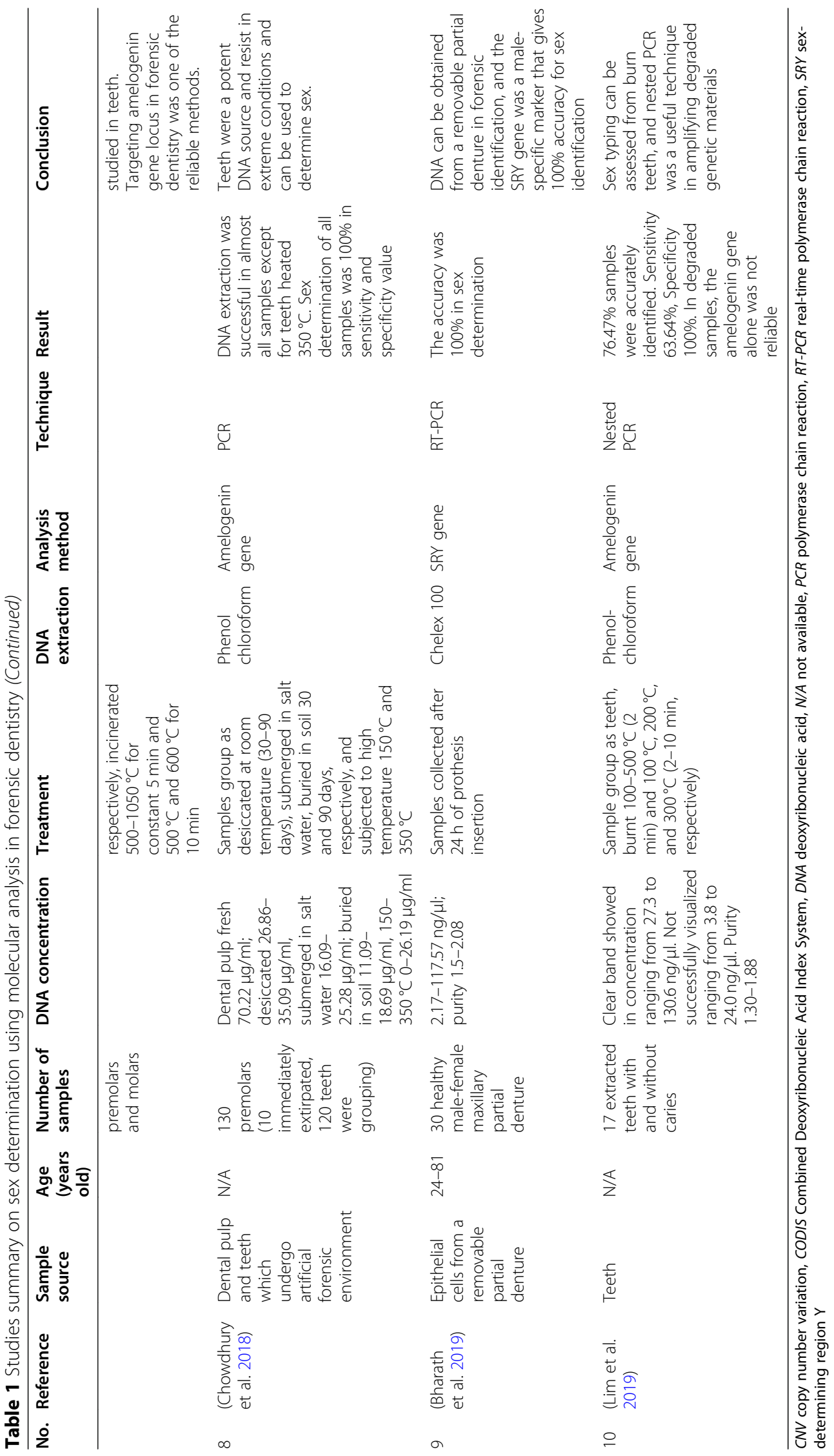


(Zapico and Ubelaker 2013; Chauhan et al. 2016; Kholief et al. 2017; Srivastava et al. 2017; Dutta et al. 2017; Chowdhury et al. 2018), RT-PCR (Reddy et al. 2011; Nakanishi et al. 2015; Bharath et al. 2019), or nested PCR (Lim et al. 2019).

The results showed that most of the studies succeeded in DNA extraction except for two studies (Srivastava et al. 2017; Chowdhury et al. 2018). The sex identification was accurately defined in six studies (Zapico and Ubelaker 2013; Chauhan et al. 2016; Kholief et al. 2017; Dutta et al. 2017; Bharath et al. 2019), and in four studies, not all samples were identified correctly (Reddy et al. 2011; Srivastava et al. 2017; Chowdhury et al. 2018; Lim et al. 2019). The conclusion from ten studies was that teeth, mesiodens, dental pulp, and dentin are reliable sources for DNA with resistance to forensic insult unless subjected to extreme degradation and that also toothbrushes and dental prostheses were good DNA sources. Amelogenin (Zapico and Ubelaker 2013; Nakanishi et al. 2015; Chauhan et al. 2016; Srivastava et al. 2017; Dutta et al. 2017; Chowdhury et al. 2018; Lim et al. 2019), SRY(Reddy et al. 2011; Kholief et al. 2017; Bharath et al. 2019), and DYS14 (Kholief et al. 2017) were all reliable in sex identification.

\section{Discussion}

The first and the most important step in identification in forensic medicine is considered to be sex determination (Herrmann and Davis 1956). Reliable sex determination by definition requires $80 \%$ accuracy, and the expected accuracy of sex estimation in most DNA analysis would reach 100\% (Capitaneanu et al. 2017b).

The samples in the reviewed studies were obtained mostly from dentin and pulp while others varied from teeth, dentinal pulp, intraoral epithelial cells from buccal swabs, toothbrushes, prothesis, and saliva from dental prosthesis. Decomposed or burning teeth can leave dentin and pulp protected by the enamel. Some studies have used tooth samples from sound and carious teeth (Kholief et al. 2017; Dutta et al. 2017; Lim et al. 2019) to see differences in DNA extraction and amplification. Other studies have selected intact teeth from mesiodens (Srivastava et al. 2017) or periodontitis (Zapico and Ubelaker 2013). The intact and carious teeth were examined for the corresponding forensic state, with PCR visualization after DNA extraction.

The subjects' age range was only mentioned in three studies. The other studies do not characterize the specific subject samples, and one study obtained tooth samples from anonymous donors (Zapico and Ubelaker 2013), maybe because in DNA analysis, age information is not as important as in morphological and metric dental measurements to determine sex.

The sample size varied in a wide range (6-130), and the smaller sample size focused on the extraction DNA from dental prosthesis patients after a period of storage that was applicable for human identification without mentioning sensitivity or specificity (Chauhan et al. 2016). A study with larger samples grouped samples for mimicking natural post-mortem insults during death and body decomposition (Chowdhury et al. 2018).

DNA extraction in the studies used Chelex 100, silicabased method, and phenol-chloroform methods. Phenolchloroform is less expensive than a silica-based method but has disadvantages such as time consumption, difficulty and demanding of large quantity samples, and possible contamination of proteins because the samples need to be transferred between multiple tubes and hazardous chemicals (Butler 2012). Chelex technique is quick, has few manipulating steps, and does not use hazardous chemicals such as phenol-chloroform (Ali et al. 2017). The silica-based method also does not require a DNA precipitation step so it decreases the contamination of proteins and potential chemical injury to the researcher compared to the phenol-chloroform approach (Zapico and Ubelaker 2013).

In this study, in the DNA concentration, some were highly detected, some detected in low concentration, or some not detected. In epithelial cells, Nakanishi et al. set the required minimum amount of template DNA for correct sex determination as more than $0.2 \mathrm{ng}(t$ test, $p$ $<0.01$ ) (Nakanishi et al. 2015). One method in detecting minute DNA concentration was by increasing the sample volume from 1 to $2 \mu \mathrm{l}$ (Zapico and Ubelaker 2013) or by increasing the number of PCR cycles from $30-35$ cycles to 45 cycles (Dutta et al. 2017).

DNA degradation occurred in samples that were exposed to humidity, light, bacterial and fungal contamination, and also elevated temperature. Special treatments were enforced in some samples to resemble the degrading forensic environment in seven studies. Tooth desiccation for 1 to 3 months resulted in a constant decline of DNA with the time of exposure (Reddy et al. 2011; Dutta et al. 2017; Chowdhury et al. 2018). Another study was leaving teeth at room temperature for $0,2,5$, and 10 years showed declining DNA concentration for the first 2 years but no significant further decline of DNA concentration up to 10 years (Rubio et al. 2009). Sex was more frequently incorrectly identified after 3 months of desiccation than after a shorter time of exposure (Reddy et al. 2011). Nevertheless, compared to other treatments mimicking forensic environments, desiccated teeth mostly presented no interference for sex determination.

Dental samples submerged in saltwater or seawater for 1 to 3 months result in degraded DNA but sex determination was still accurate (Dutta et al. 2017; Chowdhury et al. 2018). Three studies experiment teeth undergone incineration at $500-1050{ }^{\circ} \mathrm{C}$ for $5 \mathrm{~min}$ and $500{ }^{\circ} \mathrm{C}$ and $600^{\circ} \mathrm{C}$ for $10 \mathrm{~min}$, respectively (Dutta et al. 2017). From all samples, their genomic DNA retrieval 
and sex determination had a favorable outcome with an increasing number of PCR cycles. Another study with incineration at $150{ }^{\circ} \mathrm{C}, 250^{\circ} \mathrm{C}$, or $350^{\circ} \mathrm{C}$ could not retrieve genomic DNA after burning at $350^{\circ} \mathrm{C}$ (Chowdhury et al. 2018). Yet another study burnt teeth at $100-500^{\circ} \mathrm{C}$ for 2 min and at $100{ }^{\circ} \mathrm{C}, 200{ }^{\circ} \mathrm{C}$, and $300^{\circ} \mathrm{C}$ for $2-10 \mathrm{~min}$ ( $\mathrm{Lim}$ et al. 2019). The degraded DNA was only detected in $35.3 \%$ of cases in external PCR amplification by nested PCR, but in $94.12 \%$ of cases, sex was successfully identified by internal amplification. Using ultraviolet radiation $(0.2$ or $0.4 \mathrm{~J})$, DNA degraded with the increased energy of ultraviolet irradiation, but in this study, sex determination also could be accomplished (Nakanishi et al. 2015).

Burial to the depth of about $10 \mathrm{~cm}$ in garden soil has been applied to degrade DNA. Such DNA also can be retrieved for successful sex determination by nested PCR (Dutta et al. 2017; Lim et al. 2019).

Six studies have applied the amelogenin gene method for analysis. However, the presented amplicons have different length, which were $106 \mathrm{bp}(\mathrm{X})$ and $112 \mathrm{bp}(\mathrm{Y})$ (Zapico and Ubelaker 2013), 281 bp (X) and 287 (Y) (Lim et al. 2019), $330 \mathrm{bp}(\mathrm{X})$ and 236 (Y) (Chowdhury et al. 2018), $1.5 \mathrm{~kb}(\mathrm{X})$ and $\sim 1.3 \mathrm{~kb}$ (Y)(Dutta et al. 2017), and $71 \mathrm{bp}(\mathrm{X})$ and $93 \mathrm{bp}(\mathrm{Y})$ (Nakanishi et al. 2015) in PCR amplification. Male subjects showed two amplicons (X-Y) while females showed a single amplicon in X-form.

Amelogenin produced from ameloblast, so specifically present in the enamel, but later ameloblast also found in an apical area of developing roots (Eastoe 1979). Several studies then found amelogenin mRNA and protein in mineralized tissue, in cells such as osteoclast, osteoblast, chondrocytes, and cementoblast (Hatakeyama et al. 2003). The expression of amelogenin in 2006 revealed also discovered in soft tissue (brain and eye) (Deutsch et al. 2006; Frasheri et al. 2016). The weak point of the amelogenin method is the possibility of deletion events on Yp in the amelogenin (Chen et al. 2014). Cases of failure in the amelogenin test could use the DXYS156 locus method.

The DXYS156 was a locus-like amelogenin but spare internal positive control in the X alleles. DXYS156 is also multi-allelic, with the advantage of higher power of discrimination than amelogenin (Butler and Li 2014). Another method was used as a combination between RT-PCR and copy number of variation (CNV) (Nakanishi et al. 2015). CNV is caused by duplication, deletion, or multiplication of a certain gene selection. Thus, in the forensic sample, if the CNV technique can detect $\mathrm{X}$ chromosome amelogenin genes and correspond to the copy number of $\mathrm{X}$ chromosomes, then the female gender can be identified directly. This method was found to deal with misidentification in sex determination because of amelogenin-Y dropout due to deletion, translocation, and other mutations in the primer-binding site that is related to disease susceptibility (Ou et al. 2011).
Sertoli cells in testes express the SRY gene for making a protein called sex-determining region $Y$ protein that is responsible for the initiation of male sex (McClelland et al. 2012). To detect the SRY gene, sampling can use blood, saliva, teeth, or epithelial cells (Reddy et al. 2011; Bharath et al. 2019). Two studies successfully identified sex with SRY (Kholief et al. 2017; Bharath et al. 2019), while in one study (Bharath et al. 2019), 26.7\% of cases were wrongly identified females as males from SRY status. However, such misidentification only occurred in 10\% (1 of 10) of the cases when the samples were stored at room temperature for up to 30 days, but in $60 \%$ ( 3 of 5) of the cases when the storage time was 60 days (Bharath et al. 2019). The SRY gene has some limitations from conditions such as Klinefelter syndrome (46, XXY), Turner syndrome (46, X0), mutations in the SRY gene like Swyer syndrome (46, XY), pure or partial gonadal dysgenesis, the testicular disorder of sex development (46, XX), androgen insensitivity syndrome, XYY syndrome, and 5-alpha-reductase deficiency (US National Library of Medicine 2019).

The DYS14 gene is a marker located in the multicopy Y-encoded testis-specific protein (TPSY) in intron 1, playing a role in spermatogenesis (Campos et al. 2014). More than 50 copies of this gene reside in the $\mathrm{Y}$ chromosome, and each copy carries the DYS14 marker. The genomic DNA DYS14 marker appears widely in tissues and can be obtained from blood specimens, saliva, or intraoral epithelial cells (Blagodatskikh et al. 2010; Masuyama et al. 2017).

Forensic cases must be able to detect small amounts of male DNA mixed with an abundance of female DNA, thus making the study of the $\mathrm{Y}$ chromosome of importance (Campos et al. 2014). There were three studies (Reddy et al. 2011; Kholief et al. 2017; Bharath et al. 2019) targeting the SRY and one study (Kholief et al. 2017) using combined SRY and DYS14. The DYS14 gene in SRY and DYS14 combination was used to verify the efficacy for sex determination from tooth pulp. The DYS14 gene can also identify male DNA in a mixture of male and female blood samples (Barra et al. 2015) and in a mixture of male and female saliva samples (Kamodyova et al. 2013). In a study of non-invasive fetal gender (Jacob et al. 2015), the combined use of DYS14 and SRY recognized correctly $100 \%$ of samples from male-bearing pregnancy while two male samples with SRY gave false-negative results.

The DNA amplification techniques used in this study were PCR, RT-PCR, and nested PCR. The polymerase chain reaction (PCR) allows the amplification of single molecules of target DNA to analytical quantities. The limited amount of samples in forensic cases can be solved by modification in amplification. The number of PCR cycles increased by 10 cycles for adequate amplification in degraded DNA (Dutta et al. 2017). This resulted in $100 \%$ retrieval of genomic DNA. 
The RT-PCR and nested PCR have high sensitivity, automation feasibility, and high throughput. In the RT-PCR technique, chromosomes $\mathrm{X}$ or $\mathrm{Y}$ were identified by counting the chromosomes for sex determination. $\mathrm{X}$ chromosomes were counted using a comparative $(\Delta \Delta \mathrm{Ct})$ method (Reddy et al. 2011; Bharath et al. 2019), while in SRY, Y chromosomes were counted (Nakanishi et al. 2015). In the nested PCR study, based on the ratio of after and before nested PCR of amelogenin, the sensitivity of sex typing in the amelogenin gene showed a 9.5-fold increase (Lim et al. 2019). Therefore, degraded DNA can be analyzed with this technique. The disadvantage of RT-PCR and is prone to false-positive results compared to PCR (Kholief et al. 2017) and the possibility of random dropout when a very low copy number initiates real-time PCR which causes sex determination failure (Alonso and Martin 2005).

The minimum/mean levels of accuracy of sex determination in seven studies with amelogenin and two studies with SRY were $75.0 / 93.0 \%$ and $86.7 / 93.3 \%$, respectively. Only one study applied combined SRY and DYS14, with $100 \%$ reported minimum (and mean) accuracy. It is challenging to generalize the results, as the samples were not from standardized sources or conditions before the analysis. Only some of the studies varied the methods of analysis or mimicked the environmental exposure to the samples similarly as in actual forensic cases. While sex determination appears reasonably reliable by using DNA tracing of amelogenin, SRY, or combined SRY and DYS14, the expected accuracy will decline with time and with exposure to a degrading environment.

\section{Conclusion}

The reviewed ten studies on sex determination by DNA tracing from oral tissue remnants showed that amelogenin, SRY, and DYS14 were reasonably reliable indicators for the purpose. Accuracy of the results may improve by applying particular techniques such as the copy variation method when tracing amelogenin, by using gender-specific indicators such as the Y chromosome marker SRY gene, or combined markers like SRY together with DYS14. In real forensic cases, clinicians must choose the appropriate method according to the case specifics such as the available body remnants and their degradation.

\footnotetext{
Abbreviations

CNV: Copy number variation; CODIS: Combined deoxyribonucleic acid index system; DNA: Deoxyribonucleic acid; HMG box: High mobility group box; N/ A: Not available; PCR: Polymerase chain reaction; PRISMA: Preferred reporting items for systematic reviews and meta-analyses; RT-PCR: Real-time polymerase chain reaction; SRY: Sex-determining region Y; TPSY: Testisspecific protein, $Y$-linked
}

\section{Authors' contributions}

C.M. conducted literature research, analysis, and interpretation of data and drafted the work. E.I.A. contribute to the design of the study, supervised and revised it critically for important intellectual content, and approved the version to be published. All authors have read and approved the final manuscript.

\section{Funding \\ None \\ Availability of data and materials \\ Not applicable}

Ethics approval and consent to participate

Not applicable

\section{Consent for publication}

Not applicable

\section{Competing interests}

The authors declare that they have no competing interests.

\section{Author details}

${ }^{1}$ Faculty of Dentistry, Universitas Indonesia, Jakarta, Indonesia. ${ }^{2}$ Department of Oral Biology, Faculty of Dentistry, Universitas Indonesia, Jakarta, Indonesia.

Received: 7 July 2020 Accepted: 27 October 2020

Published online: 05 November 2020

\section{References}

Ali N, Rampazzo RCP, Costa ADT, Krieger MA (2017) Current nucleic acid extraction methods and their implications to point-of-care diagnostics. Biomed Res Int 2017:9306564. https://doi.org/10.1155/2017/9306564

Alonso A, Martin P (2005) A real-time PCR protocol to determine the number of amelogenin $(X-Y)$ gene copies from forensic DNA samples. Methods Mol Biol 297:31-44. https://doi.org/10.1385/1-59259-867-6:031

Bansal AK, Shetty DC, Bindal R, Pathak A (2012) Amelogenin: a novel protein with diverse applications in genetic and molecular profiling. J Oral Maxillofac Pathol 16(3):395-399. https://doi.org/10.4103/0973-029X.102495

Barra GB, Santa Rita TH, Chianca CF, Velasco LF, de Sousa CF, Nery LF et al (2015) Fetal male lineage determination by analysis of Y-chromosome STR haplotype in maternal plasma. Forensic Sci Int Genet 15:105-110. https://doi. org/10.1016/j.fsigen.2014.11.006

Basman RS, Puspita AD, Achmad RT, Suhartono AW, Auerkari El (2018) Palatal rugae comparison between ethnic Javanese and non-Javanese. J Phys 1025. https://doi.org/10.1088/1742-6596/1025/1/012046/pdf

Bharath TS, Saraswathi TR, Suresh Sajjan MC, Ramchandran CR, Govindraj Kumar N (2019) Isolation and quantification of DNA from epithelial cells obtained from acrylic removable partial denture for sex identification. Egypt J Forensic Sci 9(1):19. https://doi.org/10.1186/s41935-019-0123-9

Blagodatskikh EG, Nikitin AG, Seregin YA, Blagodatskikh KA, Nosikov W (2010) Sex determination in biological specimens using the DYS14 marker. Mol Biol 44(4):568-570. https://doi.org/10.1134/s0026893310040102

Butler E, Li R (2014) Genetic marker for sex identification in forensic DNA analysis. J Forensic Investig 2(2):10 https://www.avensonline.org/wp-content/uploads/ JFI-2330-0396-02-0013.pdf

Butler J (2012) DNA Extraction Methods. In: Butler J (ed) Advanced topics in forensic DNA typing: Methodology. Academic Press, USA

Campos EA, Pitta DR, Costa FA, Campos VM, Yela D, Fernandes A (2014) DNA extraction from filter-paper spots of vaginal samples collected after sexual violence. Int J Gynaecol Obstet 126(1):23-27. https://doi.org/10.1016/j.ijgo. 2014.02.010

Capitaneanu C, Willems G, Jacobs R, Fieuws S, Thevissen P (2017b) Sex estimation based on tooth measurements using panoramic radiographs. Int J Legal Med 131(3):813-821. https://doi.org/10.1007/s00414-016-1434-0

Capitaneanu C, Willems G, Thevissen P (2017a) A systematic review of odontological sex estimation methods. J Forensic Odontostomatosol 35(2):119 https://www.ncbi.nlm.nih.gov/pmc/articles/PMC6100233/pdf/JFOS-35-2-1. pdf

Chauhan I, Sugirtharaj G, Sathyan S, Beena VT, Banerjee M (2016) Evaluation of salivary DNA obtained from dental prosthesis and its applicability in forensic 
investigations. J Forensic Leg Med 42:100-105. https://doi.org/10.1016/j.jlm. 2016.05.015

Chen H, Lowther W, Antonarakis S (1994) Homologous loci DXYS156X and DXYS156Y contain a polymorphic pentanucleotide repeat (TAAAA), and map to human $X$ and $Y$ chromosomes. Hum Mutat 4(3):208-211. https://doi.org/ 10.1002/humu. 1380040306

Chen W, Wu W, Cheng J, Zhang Y, Chen Y, Sun H (2014) Detection of the deletion on Yp11.2 in a Chinese population. Forensic Sci Int Genet 8(1):7379. https://doi.org/10.1016/j.fsigen.2013.07.003

Chowdhury R, Singhvi A, Bagul N, Bhatia S, Singh G, Goswami S (2018) Sex determination by amplification of amelogenin gene from dental pulp tissue by polymerase chain reaction. Indian J Dent Res 29(4):470-476. https://doi. org/10.4103/ijdr.IJDR_274_17

da Silva R, Sales-Peres A, de Oliveira R, F dO, Sales-Peres S (2007) Use of DNA technology in forensic dentistry. J Appl Oral Sci 15(3):156-161. https://doi.org/ 10.1590/S1678-77572007000300002.

Deutsch D, Haze-Filderman A, Blumenfeld A, Dafni L, Leiser Y, Shay B (2006) Amelogenin, a major structural protein in mineralizing enamel, is also expressed in soft tissues: brain and cells of the hematopoietic system. Eur J Oral Sci 114(Suppll):183-189. https://doi.org/10.1111/j.1600-0722.2006.00301.x

Dutta P, Bhosale S, Singh R, Gubrellay P, Patil J, Sehdev B et al (2017) Amelogenin gene - the pioneer in gender determination from forensic dental samples. J Clin Diagn Res 11(2):ZC56-ZC59. https://doi.org/10.7860/JCDR/2017/22183.9407

Eastoe J (1979) Enamel protein chemistry - past, present and future. J Dent Res 58(Spec Issue B):753-764. https://doi.org/10.1177/00220345790580022701

Frasheri I, Ern C, Diegritz C, Hickel R, Hristov M, Folwaczny M (2016) Full-length amelogenin influences the differentiation of human dental pulp stem cells. Stem Cell Res Ther 7:10. https://doi.org/10.1186/s13287-015-0269-9

Harley V, Goodfellow P (1994) The biochemical role of SRY in sex. Mol Reprod Dev 39:184-193. https://doi.org/10.1002/mrd.1080390211

Hatakeyama J, Sreenath T, Hatakeyama Y, Thyagarajan T, Shum L, Gibson CW et al (2003) The receptor activator of nuclear factor-kB ligand-mediated osteoclastogenic pathway is elevated in amelogenin-null mice. J Biol Chem 278(37):35743-35748. https://doi.org/10.1074/jbc.M306284200

Herrmann W, Davis A (1956) The determination of chromosomal sex by oral smears. Yale J Biol Med 29(1):69-74 https://www.ncbi.nlm.nih.gov/pmc/ articles/PMC2603720/pdf/yjbm00640-0092.pdf

Jacob RR, Saxena R, Verma IC (2015) Noninvasive diagnosis of fetal gender: utility of combining DYS14 and SRY. Genet Test Mol Biomarkers 19(9):505-511. https://doi.org/10.1089/gtmb.2015.0040

Jacot TA, Zalenskaya I, Mauck C, Archer DF, Doncel GF (2013) TSPY4 is a novel sperm-specific biomarker of semen exposure in human cervicovaginal fluids; potential use in HIV prevention and contraception studies. Contraception 88(3):387-395. https://doi.org/10.1016/j.contraception.2012.11.022

Kamodyova N, Durdiakova J, Celec P, Sedlackova T, Repiska G, Sviezena B et al (2013) Prevalence and persistence of male DNA identified in mixed saliva samples after intense kissing. Forensic Sci Int Genet 7(1):124-128. https://doi. org/10.1016/j.fsigen.2012.07.007

Kholief M, El Shanawany S, Gomaa R (2017) Sex determination from dental pulp DNA among Egyptians. Egypt J Forensic Sci 7(1):29. https://doi.org/10.1186/ s41935-017-0030-x

Lim JJ-Y, Khamis MF, Abd Rashid NH (2019) Identification of amelogenin gene on burnt teeth samples through nested polymerase chain reaction amplification for sex identification. Jurnal Sains Kesihatan Malaysia 17(01):91-98. https://doi. org/10.17576/jkm-2019-1701-12

Luthfi M, Suhartono W, Puspita AD, Auerkari El (2017) Third molar development age range on indonesian population from various ethnics based on radiograph findings: a preliminary study. J Int Dent Med Res 10(2):299-302 http://www.jidmr.com/journal/wp-content/uploads/2017/05/18_53.\%20L_M_ Luthfi_EA.pdf

Macaluso P (2010) Sex discrimination potential of maxillary molar cusp diameters. J Forensic Odontostomatosol 28(1):22-31 http://www.iofos.eu/Journals/ JFOS\%20Dec10/4_discriminationPotential.pdf

Masuyama K, Shojo H, Nakanishi H, Inokuchi S, Adachi N (2017) Sex determination from fragmented and degenerated DNA by amplified product-length polymorphism bidirectional SNP analysis of amelogenin and SRY genes. PLoS One 12(1):e0169348. https://doi.org/10.1371/journal.pone. 0169348

McClelland K, Bowles J, Koopman P (2012) Male sex determination: insights into molecular mechanisms. Asian J Androl 14(1):164-171. https://doi.org/10. 1038/aja.2011.169
Moher D, Liberati A, Tetzlaff J, Altman D (2009) Preferred Reporting Items for Systematic Reviews and Meta-Analyses: the PRISMA statement. Ann Intern Med 151:264-269. https://doi.org/10.1371/journal.pmed.1000097

Morikawa T, Yamamoto Y, Miyaishi S (2011) A new method for sex determination based on detection of SRY, STS and amelogenin gene regions with simultaneous amplification of their homologous sequences by a multiplex PCR. Acta Med Okayama 65(2):113-122. https://doi.org/10.18926/AMO/45270

Mukerjee S, Mukherjee M, Ghosh T, Kalpana D, Sharma AK (2013) Differential pattern of genetic variability at the DXYS156 locus on homologous regions of $X$ and $Y$ chromosomes in Indian population and its forensic implications. Int J Legal Med 127(1):1-6. https://doi.org/10.1007/s00414-011-0646-6

Nakahori Y, Takenaka O, Nakagome Y (1991) A human X-Y homologous region encodes "amelogenin". genomics 9:264-269. https://doi.org/10.1016/08887543(91)90251-9

Nakanishi H, Shojo H, Ohmori T, Hara M, Takada A, Adachi N et al (2015) A novel method for sex determination by detecting the number of $\mathrm{X}$ chromosomes. Int J Legal Med 129(1):23-29. https://doi.org/10.1007/s00414-014-1065-2

Ou X, Chen W, Chen H, Zhao F, Zheng J, Tong D et al (2011) Null alleles of the X and $\mathrm{Y}$ chromosomal amelogenin gene in a Chinese population. Int J Legal Med 126(4):513-518. https://doi.org/10.1007/s00414-011-0594-1

Reddy AVS, Sriram G, Saraswathi TR, Sivapathasundharam B (2011) Isolation of epithelial cells from tooth brush and gender identification by amplification of SRY gene. J Forensic Dent Sci 3(1):27-32. https://doi.org/10.4103/09751475.85293

Roewer L (2019) Y-chromosome short tandem repeats in forensics—sexing, profiling, and matching male DNA. Wiley Interdiscip Rev 1:e1336. https://doi. org/10.1002/wfs 2.1336

Rubio L, Martinez L, Martinez E, Martin de las Heras S (2009) Study of short- and long-term storage of teeth and its influence on DNA. J Forensic Sci 54(6): 1411-1413. https://doi.org/10.1111/j.1556-4029.2009.01159.x.

Sasaki S, Shimokawa H (1995) The amelogenin gene. Int J Dev Biol 39:127-133 http://www.ijdb.ehu.es/web/descarga/paper/7626398

Silva AM, Pereira ML, Gouveia S, Tavares JN, Azevedo A, Caldas IM (2016) A new approach to sex estimation using the mandibular canine index. Med Sci Law 56(1):7-12. https://doi.org/10.1177/0025802415575415

Sinclair A, Berta P, Palmer M, Hawkins J, Griffiths B, Smith M et al (1990) A gene from the human sex-determining region encodes a protein with homology to a conserved DNA-binding motif. Nature 346:240-244. https://doi.org/10. 1038/346240a0

Srivastava M, Tripathi S, Astekar M, Singal D, Srivastava A, Vashisth P (2017) Sex determination from mesiodens of Indian children by amelogenin gene. J Forensic Dent Sci 9(3):125-129 https://www.ncbi.nlm.nih.gov/pmc/articles/ PMC5887634/

Suhartono AW, Syafitri K, Puspita AD, Soedarsono N, Gultom FP, Widodo PT et al (2016) Palatal rugae patterning in a modern Indonesian population. Int J Legal Med 130:881-887. https://doi.org/10.1007/s00414-015-1272-5

US National Library of Medicine. SRY gene sex-determining region. 2019. https:// ghr.nlm.nih.gov/gene/SRY. Accessed: 19 May 2019

Zapico SC, Ubelaker DH (2013) Sex determination from dentin and pulp in a medicolegal context. J Am Dent Assoc 144(12):1379-1385. https://doi.org/10. 14219/jada.archive.2013.0074

\section{Publisher's Note}

Springer Nature remains neutral with regard to jurisdictional claims in published maps and institutional affiliations. 